\title{
Antibiofilm potential of Psidium guajava and Passiflora edulis pulp extracts against Staphylococcus aureus, cytotoxicity, and interference on the activity of antimicrobial drugs
}

Renan Martins dos Santos ${ }^{1,2}$, Gustavo Costa ${ }^{3}$, Isabela Pena Cerávolo ${ }^{4}$ and Marcus Vinícius Dias-Souza ${ }^{1,2^{*}}$ (1)

\begin{abstract}
Background: Pathogenic strains of Staphylococcus aureus can cause several diseases including septicemia and endocarditis, in spite of being a commensal species of the human microbiota. The current drug resistance of $S$. aureus raises the need for new antimicrobials, and natural products represent a feasible source for prospection of such compounds, due to features including the diversity of structures and mechanisms of action. Here, we provide evidence of the antimicrobial activity of methanolic of Psidium guajava and Passiflora edulis pulps against planktonic cells and biofilms of clinical isolates of $S$. aureus.

Results: The extracts were effective against the strains in concentrations up to 7.81 and $250 \mu \mathrm{g} / \mathrm{mL}$ for planktonic cells and biofilms, respectively. Antagonistic interactions of the extracts to antimicrobial drugs were observed. The pulps caused no cytotoxic effects on BGM cells. GC-MS analysis found relevant molecules, and UPLC analysis suggested the presence of flavonoids. To the best of our knowledge, this is the first antibiofilm evidence of such extracts.
\end{abstract}

Conclusion: The extracts seem to be safe and effective enough for more studies aiming at exploring isolated antimicrobial molecules using in vivo models for the treatment of staphylococcal diseases.

Keywords: Staphylococcus aureus, Fruit pulp, Psidium guajava, Passiflora edulis

\section{Background}

Staphylococcus aureus is a commensal bacterium that can be found in the skin and in nasal mucosa, and around $30 \%$ of the human population is colonized with this species [1]. S. aureus is also an important pathogen associated to diseases such as infective endocarditis, osteomielitis, septicemia, infections related to devices such as catheters and stents, and skin/soft tissues

\footnotetext{
* Correspondence: souzamvd@gmail.com

'Clinical Analysis Laboratory, Pitagoras College, Ipatinga, MG, Brazil ${ }^{2}$ Integrated Pharmacology and Drug Interactions Research Group (GPqFAR), Ipatinga, MG, Brazil

Full list of author information is available at the end of the article
}

infections like abscesses, pleuropulmonary infection, and purulent cellulitis [2-4]. The growing resistance of $S$. aureus to the currently available antimicrobial drugs is a critical issue for treatment of infectious diseases caused by this species: as the strains develop varied mechanisms of drug resistance such as biofilm formation, production of drug degrading enzymes, and expression of efflux pumps, the effectiveness of antimicrobials drugs is hampered $[2,5]$. In this context, natural products of vegetable origin are important sources of antimicrobial compounds. Most of the studies on herbal-based antimicrobials provide evidence of lack of resistance mechanisms, and compared to the development of synthetic

\section{Springer Open}

() The Author(s). 2020 Open Access This article is licensed under a Creative Commons Attribution 4.0 International License, which permits use, sharing, adaptation, distribution and reproduction in any medium or format, as long as you give appropriate credit to the original author(s) and the source, provide a link to the Creative Commons licence, and indicate if changes were made. The images or other third party material in this article are included in the article's Creative Commons licence, unless indicated otherwise in a credit line to the material. If material is not included in the article's Creative Commons licence and your intended use is not permitted by statutory regulation or exceeds the permitted use, you will need to obtain permission directly from the copyright holder. To view a copy of this licence, visit http://creativecommons.org/licenses/by/4.0/. 
drugs, the costs on the development of phytoformulations are considerably lower.

Psidium guajava is common in tropical and subtropical countries, and the fruit (guava) is used for artisanal and industrial manufacturing of jellies, sweets, powder fibers, and juice [6,7]. Extracts of different parts of $P$. guajava present antibacterial and antifungal activities and are popularly used for epilepsy, convulsions, diarrhea, stomachache, constipation, wound healing, and diabetes [8-11]. Guava juice is specially appreciated, and pulps are prepared in order to allow the consumption of the juice throughout the year, avoiding seasonal influences on the availability of fruit $[11,12]$. However, the biological potentials of the pulp are poorly investigated.

Passiflora species are also present in tropical and subtropical countries, and more than 500 species of the plant are known [13, 14]. In Brazil, Passiflora edulis has an important economic role. The pulp is largely used for juice preparation, the dry powder of the epicarp is used for diabetes and lipid metabolism disorders, and leaf extract is used for the treatment of sleep and gastric disorders [15-19]. The leaf and stem bark extracts are effective against microbial species such as Bacillus subtilis, S. aureus, Escherichia coli, and Pseudomonas aeruginosa [20, 21]. The biological potentials of the pulp are poorly investigated as well as for guava.

In spite of the benefits of plants to human health, data on pharmacological potential of edible vegetable parts are often scarce. With the growing resistance of $S$. aureus to the available antimicrobial drugs, an urgent need for new therapeutic options is raised. Here we show that the methanolic extracts $(80 \% \mathrm{v} / \mathrm{v})$ of $P$. guajava and $P$. edulis fruit juice pulps are effective against planktonic cells and biofilms of clinical isolates of S. aureus. We conducted ultra-performance liquid chromatography (UPLC) and gas chromatography coupled to mass spectrometry (GC-MS) analyses of the extracts and investigated the effects of the joint use of the extracts and clinically relevant antimicrobial drugs, and observed mostly antagonistic responses. Moreover, we conducted toxicity tests against BGM cells. Our data open doors for isolating and exploring antimicrobial molecules of $P$. guajava and $P$. edulis pulp extracts for the treatment of staphylococcal diseases.

\section{Methods}

Pulp samples and preparation of the methanolic extract

$P$. guajava and $P$. edulis industrialized liquid pulps used in this study belong to a brand widely commercialized in Brazil (probably the most commercialized concerning fruit pulps) and were purchased at a local market in plastic bottles. They were disposed in environmental temperature and protected from sunlight. The manufacturer describes at the label that the pulps were pasteurized and are free of sucrose. The labels indicated the presence of food additives like BHT (2,6-bis(1,1dimethylethyl)-4-methylphenol), ascorbic acid, and colorants. The pulps were freeze-dried prior to the preparation of the extracts, which were prepared in environmental temperature with $80 \%$ methanol/water solution through magnetic stirring at maximum speed for $48 \mathrm{~h}$. After the extraction, the content was centrifuged $\left(5000 \mathrm{~g}, 20 \mathrm{~min}, 4^{\circ} \mathrm{C}\right)$ and the supernatant was freeze-dried. The final product was then weighed and stored at $4{ }^{\circ} \mathrm{C}$ until used.

\section{Polyphenol detection by ultra-proficiency liquid chromatography}

The polyphenol content of the methanolic extracts of the pulps was analyzed using a C18 column (Waters) in an UPLC system coupled to a diode array (UPLC/DAD) (Acquity H-Class Bio, Waters, Germany), following a method previously described by our group [22]. The column temperature was set at $35^{\circ} \mathrm{C}$. A linear gradient mode was programmed as follows: $20 \% \mathrm{~A}$ and $80 \% \mathrm{~B}$ at start, then $30 \% \mathrm{~A}$ and $70 \% \mathrm{~B}$ at $4 \mathrm{~min}, 70 \% \mathrm{~A}$ and $30 \% \mathrm{~B}$ at $6 \mathrm{~min}$, falling to $100 \% \mathrm{~A}$ and $0 \% \mathrm{~B}$ at $8 \mathrm{~min}$, and finally, 20\% A and $80 \%$ B at 10 min. Polyphenols were detected at $280 \mathrm{~nm}$.

\section{Detection of free carbohydrates and volatile components} by gas chromatography-mass spectrometry

Free carbohydrates and volatile molecules of the pulps were analyzed following a GC-MS method in positive mode previously described by our group [23]. Using HPLC grade dichloromethane, helium as carrier gas, and DB-5 column, we proceeded to the analysis in duplicate. Mass spectra and retention times obtained from each sample were matched to NIST library data for interpretation.

\section{Bacterial strains}

Clinical S. aureus isolates from indwelling catheters of hemodialysis patients were from the Clinical Laboratory of the Pitágoras College. We used VITEK 2 system (version R04.02, bioMérieux, Marcy-l'Étoile, France) grampositive identification cards to confirm the identity of 10 isolates according to the manufacturer's instructions.

\section{Minimal inhibitory concentration assay}

The minimal inhibitory concentration (MIC) of the extracts was determined in untreated sterile 96-well polystyrene microtiter plates using Mueller Hinton broth, in a final concentration of the bacterial inoculum equal to 0.5 McFarland scale and final concentrations of the extracts ranging from $1 \mathrm{mg} / \mathrm{mL}$ to $7.8 \mu \mathrm{g} / \mathrm{mL}$. Plates were incubated overnight at $35 \pm 2{ }^{\circ} \mathrm{C}$, and resazurine $0.1 \%$ solution was used to observe the antimicrobial effect. 

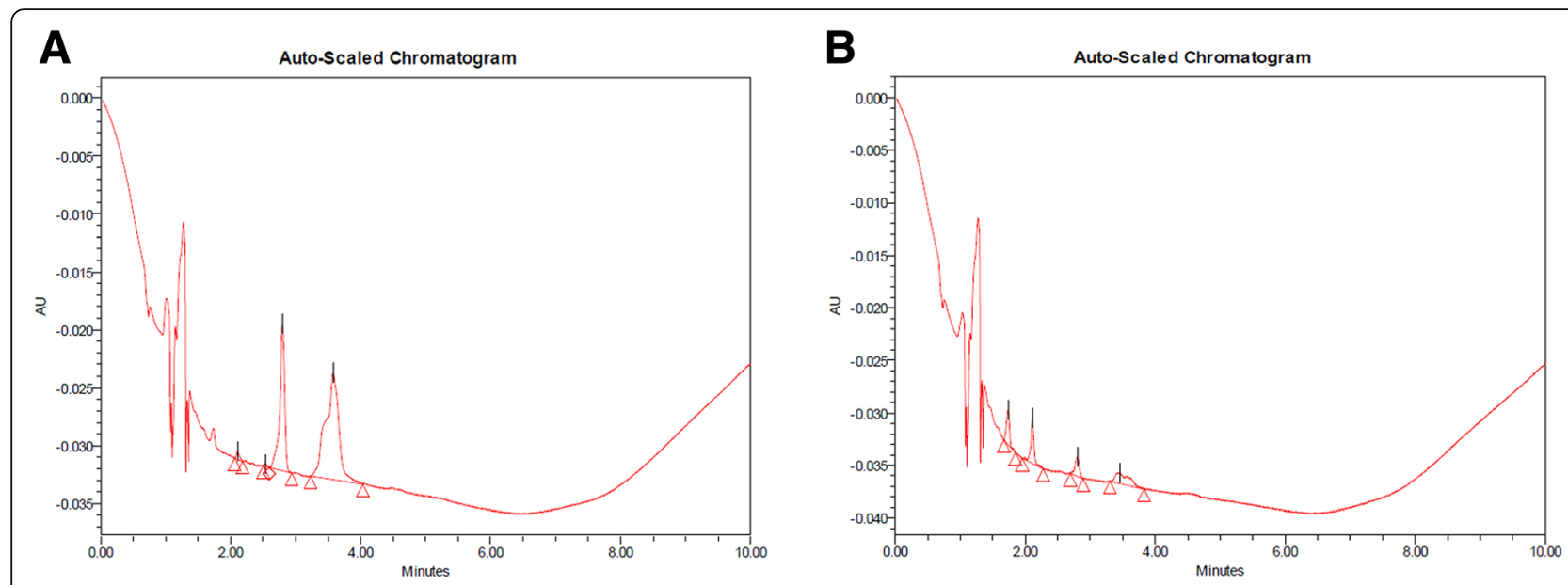

Fig. 1 UPLC chromatograms for P. edulis (a) and for P. guajava (b). Peaks were obtained using a C18 column

MIC was the lowest concentration in which no color modification from blue (resazurine) to pink (resofurine) was observed in all strains. The extracts were used as negative controls [24]. This assay was conducted in triplicate.

\section{Minimum bactericidal concentration assay}

The minimum bactericidal concentration $(\mathrm{MBC})$ of the extracts was determined in triplicate by spotting $10 \mu \mathrm{L}$ of each well of MIC plates in Mueller-Hinton agar (Difco). Extracts were inoculated as negative controls. Agar plates were incubated overnight at $35 \pm 2{ }^{\circ} \mathrm{C}$, and bacterial growth was observed. MBC was established as the lowest concentration that yielded no bacterial growth on the plates [24].

\section{Minimal biofilm eradication concentration assay}

Before minimal biofilm eradication concentration (MBEC) test, biofilm formation was induced overnight using a bacterial inoculum equal to $0.5 \mathrm{McF}$ arland scale in sterile non-treated polystyrene plates using BHI media [23]. The MBEC was then assessed in triplicate as described [24]. Aliquots of $100 \mu \mathrm{L}$ of each extract concentration were added in triplicate for each biofilm, and plates were then incubated overnight at $35 \pm 2{ }^{\circ} \mathrm{C}$. Resazurine stain was used as described in MIC for MBEC [24].

\section{Interference of the pulp extract on the activity of antimicrobial drugs}

The interference of the extracts on antimicrobial drugs was assessed in duplicate as described in previous works of our group [22-25]. Antimicrobial disks (ciprofloxacin $5 \mu \mathrm{g}$, erythromycin $15 \mu \mathrm{g}$, and gentamycin $10 \mu \mathrm{g}$, all from Laborclin) were used as for antimicrobial susceptibility assays. Following, briefly, $10 \mu \mathrm{L}$ of the extracts in their
MBC concentration was dispensed in each disk. Plates were incubated overnight at $35 \pm 2{ }^{\circ} \mathrm{C}$, and the inhibition zone mean diameter was compared with control disks (without addition of the extract). Synergism was considered if the inhibition zone mean diameter was at least 2 $\mathrm{mm}$ larger than the control, and antagonism was considered if the inhibition zone mean diameter was at least 2 $\mathrm{mm}$ shorter than the control, both with statistical significance. If the inhibition zone mean diameters were larger or shorter than the control but no statistically significant difference was detected, data was described as tendency of synergism or antagonism [22].

\section{Cytotoxicity test}

The potential cytotoxic effect of the pulp extracts was tested in duplicate using BGM cells (Sigma), as previously described [22]. Cell suspensions were prepared in RPMI 1640 media supplemented with glutamine $(0.3 \mathrm{mg} / \mathrm{L})$, penicillin $(200 \mathrm{IU} / \mathrm{mL})$, streptomycin $(100 \mu \mathrm{g} / \mathrm{mL})$, and fetal bovine serum (10\%), to reach an estimated counting of $1 \times 10^{4}$ cells in $180 \mu \mathrm{L}$. Plates were then incubated overnight at $37^{\circ} \mathrm{C}$ in humidified conditions, to allow cells to reach the logarithmic growth phase. The stock solution of each extracts was prepared and diluted in PBS. Cells were treated with $20 \mu \mathrm{L}$ of each extract as in MIC assays. Plates were incubated overnight, and cell viability was assessed by resazurine staining $(0.1 \mathrm{~g} / \mathrm{L})$ using a fluorimetric microplate reader $\left(\lambda_{\mathrm{ex}} 570 \mathrm{~nm}, \lambda_{\mathrm{em}} 590 \mathrm{~nm}\right)$. Untreated cells (extract-free RPMI media) were used as the control group. Readings were also taken from the RPMI medium with the extract to remove possible interferences on fluorescence readings.

\section{Statistics}

Normality of data was assessed through the ShapiroWilk test. Data were analyzed using ANOVA followed 
Table 1 Volatile compounds identified in P. guajava extract

\begin{tabular}{|c|c|c|c|}
\hline RT & $A \%$ & Identity & $\begin{array}{l}\mathrm{m} / \\
\mathrm{z}\end{array}$ \\
\hline 2.079 & 7.08 & L-5-Propylthiomethylhydantoin & 188 \\
\hline 2.144 & 5.54 & Ethanediamide & 88 \\
\hline 2.23 & 1.63 & L-Alanine, methyl ester & 103 \\
\hline 2.364 & 8.35 & Sulfur tetrafluoride & 108 \\
\hline 2.513 & 11.81 & Pentanoic acid, 3-methyl-4-oxo- & 130 \\
\hline 2.691 & 0.24 & Silane, diethoxydimethyl- & 148 \\
\hline 2.765 & 1.46 & Isobutyl acetate & 116 \\
\hline 3.075 & 0.06 & 2-Ethoxytetrahydrofuran & 116 \\
\hline 3.144 & 0.01 & Furfural & 96 \\
\hline 3.222 & 0.05 & 2-Azetidinone, 1-phenyl- & 147 \\
\hline 3.341 & 0.02 & Ethylbenzene & 106 \\
\hline 3.556 & 0.04 & $\begin{array}{l}\text { 5,5-Dimethyl-1,3-dioxane-2-ethanol,tert-butyldimethy|silyl } \\
\text { ether }\end{array}$ & 274 \\
\hline 3.72 & 0.01 & Butyrolactone & 86 \\
\hline 4.516 & 0.01 & 1,2-Propanediol, diacetate & 90 \\
\hline 4.787 & 0.17 & Pentanoic acid, 4-oxo-, ethyl ester & 144 \\
\hline 4.832 & 0.08 & Propanedioic acid, diethyl ester & 160 \\
\hline 4.985 & 6.64 & 1,4-Butanediol, diacetate & 174 \\
\hline 5.086 & 0.01 & 1,2,4-Triazine-3,5(2H,4H)-dione, 6-benzoylthio- & 249 \\
\hline 5.508 & 0.05 & Hepta-2,4-dienoic acid, methyl ester & 140 \\
\hline 5.652 & 0.05 & Butanedioic acid, diethyl ester & 174 \\
\hline 5.687 & 0.04 & 2(1H)-Pyridinone, 5-methyl- & 109 \\
\hline 5.726 & 0.06 & Benzene, 1-(chloromethyl)-2-fluoro- & 144 \\
\hline 5.798 & 0.19 & Benzoic acid & 122 \\
\hline 6.079 & 0.21 & Benzaldehyde, 2,4-dimethyl- & 134 \\
\hline 6.118 & 0.48 & 5-Hydroxymethylfurfural & 126 \\
\hline 6.322 & 0.08 & 1,5-Diacetoxypentane & 188 \\
\hline 6.433 & 0.35 & Butanedioic acid, hydroxy-, diethyl ester, (.+/-.)- & 190 \\
\hline 6.612 & 0.37 & Benzaldehyde, 4-propyl- & 148 \\
\hline 6.847 & 0.43 & 5-Acetoxymethyl-2-furaldehyde & 168 \\
\hline 7.175 & 0.01 & 1,3-Propanediol, 2,2-dimethyl-, diacetate & 188 \\
\hline 7.412 & 0.02 & Acetic acid, cyclohexyl ester & 142 \\
\hline 12.435 & 0.11 & Pentadecane & 212 \\
\hline 22.254 & 0.06 & Hexadecanoic acid, ethyl ester & 284 \\
\hline 23.631 & 0.01 & 7-Octadecenoic acid, methyl ester & 296 \\
\hline 24.296 & 0.01 & 7-Methyl-Z-tetradecen-1-ol acetate & 268 \\
\hline 24.398 & 0.01 & 7-Tetradecenal, (Z)- & 210 \\
\hline
\end{tabular}

by the Tukey test. The significance level was set at $p<$ 0.05 , and highly significant values were set as $p<0.01$. All analyses were carried out using Bioestat 5.0 Statistical Package for Windows.

\section{Results}

\section{Chemical analyses}

UPLC analysis confirmed the presence of phenolic compounds in the sample, as peaks were detected at $280 \mathrm{~nm}$
Table 2 Volatile compounds identified in $P$. edulis extract

\begin{tabular}{|c|c|c|}
\hline RT & $A \%$ & Identity \\
\hline 2.091 & 9.47 & N-Methoxydiacetamide \\
\hline 2.181 & 2.46 & Iminodiacetic acid \\
\hline 2.241 & 3.71 & Formic acid, propyl ester \\
\hline 2.57 & 3.52 & Silane, dimethoxydimethyl- \\
\hline 2.747 & 5.17 & Isobutyl acetate \\
\hline 3.003 & 2.37 & Propanoic acid, 2-hydroxy-, ethyl ester, (S)- \\
\hline 3.21 & 0.31 & Fucose, cyclic ethylene mercaptal \\
\hline 3.241 & 0.53 & 1,2-Ethanediol, monoacetate \\
\hline 3.538 & 0.17 & (-)-O-Acetylmalic anhydride \\
\hline 3.576 & 0.55 & Oxime-, methoxy-phenyl-_ \\
\hline 3.847 & 0.5 & 2-(2-Hydroxyethoxy)ethyl acetate \\
\hline 4.676 & 0.24 & Pentanoic acid, 4-oxo- \\
\hline 5.279 & 0.18 & Silicic acid, diethyl bis(trimethylsilyl) ester \\
\hline 5.492 & 0.19 & Hepta-2,4-dienoic acid, methyl ester \\
\hline 5.661 & 1.04 & Benzoic acid \\
\hline 6.163 & 0.23 & 1,2,3-Propanetriol, 1-acetate \\
\hline 6.252 & 0.09 & Benzeneacetic acid, ethyl ester \\
\hline 6.408 & 0.17 & Butanedioic acid, hydroxy-, diethyl ester, (.+/-.)- \\
\hline 6.586 & 0.47 & Benzaldehyde, 4-propyl- \\
\hline 6.685 & 0.1 & Butanoic acid, 3-hydroxy- \\
\hline 6.827 & 0.16 & 5-Acetoxymethyl-2-furaldehyde \\
\hline 16.706 & 0.03 & Octane, 5-ethyl-2-methyl- \\
\hline 18.836 & 0.03 & Tetradecanoic acid, ethyl ester \\
\hline 18.954 & 0.02 & Undecane, 3,8-dimethyl- \\
\hline 19.142 & 0.02 & 3-Acetoxydodecane \\
\hline 21.775 & 0.12 & n-Hexadecanoic acid \\
\hline 22.259 & 0.09 & Hexadecanoic acid, ethyl ester \\
\hline 23.628 & 0.02 & 9-Octadecenoic acid (Z)-, methyl ester \\
\hline 24.318 & 0.07 & Octadecanoic acid \\
\hline 24.837 & 0.02 & 1-Acetoxynonadecane \\
\hline 26.702 & 0.01 & Tetracosane \\
\hline 27.58 & 0.01 & Tricosane \\
\hline
\end{tabular}

(Fig. 1). GC-MS analysis indicated lack of free carbohydrates in the pulps (data not shown). However, relevant volatile compounds were found for both extracts, including alcohol derivatives of glycerol, preservants, chelating agents, fatty acids, and aldehydes (Tables 1 and 2).

Table 3 Susceptibility of S. aureus isolates to the extracts and their interference on antimicrobial drugs

\begin{tabular}{llll}
\hline & \multicolumn{4}{l}{ Antimicrobial parameter $(\mathrm{in} \mu \mathrm{g} / \mathrm{mL})$} \\
\cline { 2 - 4 } & MIC & MBC & MBEC \\
\hline P. guajava & 31.25 & 62.5 & 250 \\
P. edulis & 15.62 & 125 & 250 \\
\hline
\end{tabular}

Results are referent to all tested strains 
Table 4 Interference of the extracts on antimicrobial drugs

\begin{tabular}{|c|c|c|c|c|c|c|c|c|c|}
\hline \multirow[t]{2}{*}{ Isolate } & \multicolumn{9}{|c|}{ Drug disk inhibition zone (alone or combined to extracts) in mm } \\
\hline & Ery & Ery+PE & Ery+PG & Cip & Cip+PE & Cip+PG & Gen & Gen+PE & Gen+PG \\
\hline S. aureus 1 & 0 & 0 & 0 & 18.5 & 14 & $13^{*}$ & 15 & $17^{\dagger}$ & 16.5 \\
\hline S. aureus 2 & 0 & 0 & 0 & 18.5 & $20.5^{\top}$ & $16^{*}$ & 14.5 & 14 & 13.5 \\
\hline S. aureus 3 & 0 & $12^{*}$ & 0 & 23.5 & $19.5^{\Delta}$ & $18^{*}$ & 0 & 0 & 0 \\
\hline S. aureus 4 & 0 & $10^{4}$ & 0 & 20.5 & $18^{\Delta}$ & $17 *$ & 15.5 & 16.5 & $12.5^{\Delta}$ \\
\hline S. aureus 5 & 0 & $13.5^{\star}$ & 0 & 21 & $18^{\Delta}$ & $15.5^{*}$ & 12.5 & $18^{+}$ & $15^{\dagger}$ \\
\hline S. aureus 6 & 0 & $14^{\star}$ & 0 & 20 & $18^{\Delta}$ & $17^{*}$ & 0 & $16^{\top}$ & $15^{\top}$ \\
\hline S. aureus 7 & 0 & $11^{\star}$ & 0 & 21 & $16^{\Delta}$ & $14.5^{*}$ & 14.5 & $12.5^{\Delta}$ & 14 \\
\hline S. aureus 8 & 0 & $15^{\star}$ & 0 & 32 & $20^{\Delta}$ & $18^{*}$ & 29 & $15.5^{\Delta}$ & $14.5^{\Delta}$ \\
\hline S. aureus 9 & 0 & $15^{\star}$ & 0 & 25.5 & $20^{\Delta}$ & $17.5^{*}$ & 19 & $16.5^{\Delta}$ & $15.5^{\Delta}$ \\
\hline S. aureus 10 & 0 & 0 & 0 & 23.5 & $20^{\Delta}$ & $14^{*}$ & 15 & 16.5 & $10.5^{\Delta}$ \\
\hline
\end{tabular}

Values without any symbol are indifferent when comparing to the control.

$+P E$ addition of $P$. edulis extract at the MBC, $+P G$ addition of $P$. guajava extract at the MBC, Ery erythromycin, Cip ciprofloxacin, Gen gentamicin

Statistically significant synergism

Tendency of synergism

"Statistically significant antagonism

${ }^{\Delta}$ Tendency of antagonism

\section{Antimicrobial activity of the pulps}

The antimicrobial and antibiofilm potentials of $P$. guajava and $P$. edulis pulp extracts were investigated using overnight cultures of clinical isolates of $S$. aureus, as well as overnight-formed biofilms formed in 96-wells plates. The MIC value for $P$. edulis extract was lower than $P$. guajava extract; however, the $\mathrm{MBC}$ value for $P$. guajava extract (two times higher than the MIC value) was lower than $P$. edulis extract (eight times higher than the MIC value). For both extracts, this observation suggests their bacteriostatic effect [26]. Interestingly, the MBEC value of the extracts was the same (Table 3).

\section{Interference of the extracts on the activity of antimicrobial drugs}

The pulp extracts were prepared in their MBC concentration for this assay. The combination of $P$. guajava and erythromycin resulted in a significant synergic effect for seven out of 10 isolates $(p<0.01)$, whereas it resulted in significant antagonism $(p<0.01)$ when combined to ciprofloxacin, and some antagonism tendency when combined to gentamicin (Table 4). Conversely, P. edulis extract has not altered the susceptibility profile of the isolates when combined to erythromycin. When combined to ciprofloxacin, an antagonism tendency was observed $(p<0.05)$, and tendencies of synergism and antagonism were detected for some isolates when the pulp extract was combined to gentamicin.

\section{Cytotoxicity}

Cell toxicity was not detected for BGM cell lines, and there was no significant difference of the untreated control and the treatments with P. guajava $(p=0.058)$ and $P$. edulis $(p=0.06)$ extracts. However, there was a discrete tendency on the average readings to be lower than the control.

\section{Discussion}

Here we described the antimicrobial and antibiofilm activities of the methanolic extracts obtained from industrially manufactured $P$. guajava and $P$. edulis pulps against clinical isolates of $S$. aureus, to the best of our knowledge, for the first time. The MIC of P. guajava extract was of $31.25 \mu \mathrm{g} / \mathrm{mL}$, and the MIC of $P$. edulis extract was of $15.62 \mu \mathrm{g} / \mathrm{mL}$. Our results are consistent with the observation of others that leaf extracts of both plants present antimicrobial activity against relevant pathogenic species including S. aureus, Salmonella spp., Escherichia coli, Pseudomonas aeruginosa, Listeria monocytogenes, Vibrio parahaemolyticus, and Candida albicans in concentrations around $100 \mu \mathrm{g} / \mathrm{mL}$ [20, 21, 27-30]. A recent study described that the methanolic extract of $P$. edulis pulp prepared with the seeds was effective against an ATCC strain of $S$. aureus at $4 \mathrm{mg} / \mathrm{mL}$ [31], which is 256fold higher than the MIC value described in the present study. A possible explanation for this difference to our seed-free extract is that, beyond eventual variations of cultivation parameters (which influence on the phytomolecules of the extracts), the seeds may have released harmless molecules that worked as carbon and nitrogen sources necessary for bacterial growth.

Most of the known bacteria live as biofilms, especially when causing diseases $[24,25]$. In this study, overnightgrown biofilms of clinical isolates of $S$. aureus were eradicated with the pulp extracts at the concentration of $250 \mu \mathrm{g} / \mathrm{mL}$, considerably higher than the MIC values. Biofilms can be more than 1000-fold resistant to antimicrobial compounds when compared to planktonic 
cells, due to physical and chemical protective effects of the extracellular polymeric substances surrounding the sessile cells $[25,32]$. The antibiofilm potential of $P$. guajava leaf extract was also described [33].

L-5-Propylthiomethylhydantoin was found by GC-MS in P. guajava pulp (Table 1), and pentanoic acid was found in P. edulis pulp (Table 2). Both were described to be bacteriostatic molecules [34, 35]. UPLC analysis confirmed the presence of phenolic compounds in the sample (Fig. 1a, b). Taken together, these results help to explain the antimicrobial activity of the pulps. More analyses are being conducted to identify the polyphenols found in this study. Unexpectedly, the results obtained by GC-MS analysis indicated lack of carbohydrates in the pulps: only fucose was found in $P$. edulis extract (Table 2). The presence of carbohydrates naturally present in fruit such as fructose was expected. Soluble sugar content varies considerably within and among species depending on the age, maturity, and environmental conditions [36].

Here, we evaluated the toxicity of the extracts by using BGM cells as a model of normal mammalian cells. Toxicity against BGM cells was not observed for both pulps. Compounds that lack toxicity in such in vitro models, but are effective against microorganisms, can be safe for investigations towards the clinical use [22, 32].

\section{Conclusion}

The methanolic extract of the pulps presented antimicrobial activity in an in vitro model against $S$. aureus strains, and this potential is possibly related to the polyphenols and other molecules such as L-5-propylthiomethylhydantoin, found using UPLC and GC-MS. P. guajava combined to erythromycin resulted in significant synergic effect, but also resulted in significant antagonism when combined to ciprofloxacin. Antagonism tendency was observed for P. edulis extract combination to ciprofloxacin. Given the lacking toxicity of the extracts, in spite of the small number of strains used in this study, our data open doors for further studies with isolated molecules from the extracts using in vivo models for pharmacotherapeutic purposes, both isolated and combined to antimicrobial drugs.

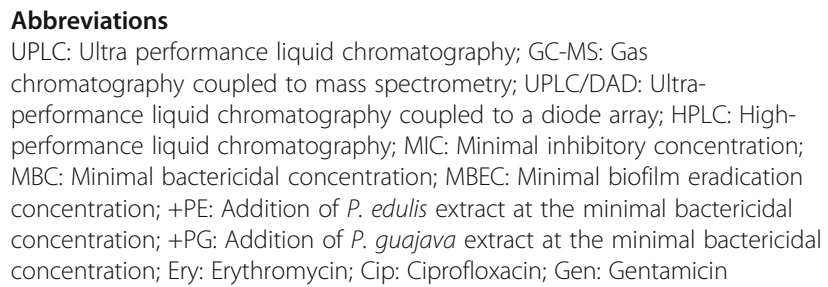

\section{Acknowledgements}

Not applicable.

\section{Plant authentication}

Plant authentication is provided by the manufacturer of the industrialized pulps used in this study.

\section{Authors' contributions}

All authors have contributed to this research work and read and approved the final version of the manuscript. RMDS, GC, MVDS: preparation of the extract, antimicrobial activity tests, and phytochemical analyzes. RMDS, GC: drafted the primary version of the manuscript. IPC: conducted cytotoxicity studies and drafted the manuscript. MVDS: conception and design of the study, statistical analysis, drafted the manuscript, and revised its final version.

\section{Funding}

This research was funded by grants of Pitagoras College given to RMDS and MVDS.

Availability of data and materials

All data and material are available upon request.

Ethics approval and consent to participate

Not applicable.

Consent for publication

Not applicable.

\section{Competing interests}

The authors declare that they have no competing interests.

\section{Author details}

${ }^{1}$ Clinical Analysis Laboratory, Pitagoras College, Ipatinga, MG, Brazil. ${ }^{2}$ Integrated Pharmacology and Drug Interactions Research Group (GPqFAR), Ipatinga, MG, Brazil. ${ }^{3}$ PharmBSc, University Center of Caratinga, Caratinga, MG, Brazil. ${ }^{4}$ René Rachou Institute, Belo Horizonte, MG, Brazil.

Received: 12 March 2020 Accepted: 15 July 2020

Published online: 05 August 2020

\section{References}

1. Mohamed MF, Hamed MI, Panitch A (2014) Seleem MN (2014) Targeting methicillin-resistant Staphylococcus aureus with short salt-resistant synthetic peptides. Antimicrob Agents Chemother. 58:4113-4122

2. Thammavongsa V, Kim HK, Missiakas D, Schneewind O (2015) Staphylococcal manipulation of host immune responses. Nat Rev Microbiol. 13:529-543

3. Arfatahery N, Davoodabadi A, Abedimohtasab T (2016) Characterization of toxin genes and antimicrobial susceptibility of Staphylococcus aureus isolates in fishery products in Iran. Sci Rep. https://doi.org/10.1038/ srep34216

4. Chaves-Moreno D, Wos-Oxley ML, Jáuregui R, Medina E, Oxley AP, Pieper DH (2016) Exploring the transcriptome of Staphylococcus aureus in its natural niche. Sci Rep. 6:33174 https://doi.org/10.1038/srep33174

5. Brackman G, Breyne K, De Rycke R, Vermote A, Van Nieuwerburgh F, Meyer E, Van Calenbergh S, Coenye T (2016) The quorum sensing inhibitor hamamelitannin increases antibiotic susceptibility of Staphylococcus aureus biofilms by affecting peptidoglycan biosynthesis and eDNA release. Sci Rep. 6:20321 https://doi.org/10.1038/srep20321

6. Rahim N, Gomes DJ, Watanabe H, Rahman SR, Chomvarin C, Endtz HP, Alam M (2010) Antibacterial activity of Psidium guajava leaf and bark against multidrug-resistant Vibrio cholerae: implication for cholera control. Jpn J Infect Dis 63(4):271-274

7. Conceição MC, Fernandes TN, de Resende JV (2016) Stability and microstructure of freeze-dried guava pulp (Psidium guajava L.) with added sucrose and pectin. J Food Sci Technol. 53:2654-2663

8. Correa MG, Couto JS, Teodoro AJ (2016) Anticancer properties of Psidium guajava - a mini-review. Asian Pac J Cancer Prev. 17:4199-4204

9. Kumari S, Rakavi R, Mangaraj M (2016) Effect of guava in blood glucose and lipid profile in healthy human subjects: a randomized controlled study. J Clin Diagn Res. 10:BC04-BC07

10. Morais-Braga MF, Carneiro JN, Machado AJ, Dos Santos AT, Sales DL, Lima LF, Figueredo FG, Coutinho HD (2016) Psidium guajava L., from ethnobiology to scientific evaluation: elucidating bioactivity against pathogenic microorganisms. J Ethnopharmacol. 194:1140-1152

11. Shafiei Z, Haji ARZ, Philip K, Thurairajah N (2016) Antibacterial and antiadherence effects of a plant extract mixture (PEM) and its individual 
constituent extracts (Psidium sp., Mangifera sp., and Mentha sp.) on singleand dual-species biofilms. PeerJ 4:e2519

12. Díaz-de-Cerio E, Pasini F, Verardo V, Fernández-Gutiérrez A, Segura-Carretero A, Caboni MF (2017) Psidium quajava L. leaves as source of proanthocyanidins: optimization of the extraction method by RSM and study of the degree of polymerization by NP-HPLC-FLD-ESI-MS. J Pharm Biomed Anal. 133:1-7

13. Otify A, George C, Elsayed A, Farag MA (2015) Mechanistic evidence of Passiflora edulis (Passifloraceae) anxiolytic activity in relation to its metabolite fingerprint as revealed via LC-MS and chemometrics. Food Funct. 6:3807-3817

14. Vaca-Vaca JC, Carrasco-Lozano EC, López-López K (2017) Molecular identification of a new begomovirus infecting yellow passion fruit (Passiflora edulis) in Colombia. Arch Virol. 162:573-576

15. Gadioli IL, da Cunha MS, de Carvalho MV, Costa AM, Pineli LL (2018) A systematic review on phenolic compounds in Passiflora plants: exploring biodiversity for food, nutrition, and popular medicine. Crit Rev Food Sci Nutr. 58:785-807

16. Nuylert A, Ishida Y, Asano Y (2017) Effect of glycosylation on the biocatalytic properties of hydroxynitrile lyase from the passion fruit, Passiflora edulis - a comparison of natural and recombinant enzymes. Chembiochem. 18:257-265

17. Silva RO, Damasceno SR, Brito TV, Dias JM, Fontenele AM, Braúna IS, Júnior JS, Maciel JS, de Paula RC, Ribeiro RA, Souza MH, Freitas AL, Medeiros JV, Silva DC, Barbosa AL (2015) Polysaccharide fraction isolated from Passiflora edulis inhibits the inflammatory response and the oxidative stress in mice. J Pharm Pharmacol. 67:1017-1027

18. Xu FQ, Wang N, Fan WW, Zi CT, Zhao HS, Hu JM, Zhou J (2016) Protective effects of cycloartane triterpenoides from Passiflora edulis Sims against glutamate-induced neurotoxicity in PC12 cell. Fitoterapia. 115:122-127

19. Zhang YJ, Zhou T, Wang F, Zhou Y, Li Y, Zhang JJ, Zheng J, Xu DP, Li HB (2016) The effects of Syzygium samarangense, Passiflora edulis and Solanum muricatum on alcohol-induced liver injury. Int J Mol Sci. 17:E1616

20. Pereira NG, Rodrigues J, Vieira L, Teofilo K, Figueiredo FJB, Dias-Souza MV (2015). Antimicrobial Potential of Passiflora alata and Piper methysticum hydroalcoholic extracts, Phytotherapics of Anxiolytic-like Activity. JAPHAC. 2: 31-33.

21. Kannan S, Parimala B, Jayakar B (2011) Antibacterial evaluation of the methanolic extract of Passiflora edulis. Hygeia J D Med. 3:46-49

22. Dias-Souza MV, Dos Santos RM, Cerávolo IP, Cosenza G, Marçal PHF (2018) Euterpe oleracea pulp extract: chemical analyses, antibiofilm activity against Staphylococcus aureus, cytotoxicity and interference on the activity of antimicrobial drugs. Microbial Pathog. 114:29-35

23. Dias-Souza MV, Dos Santos RM, Siqueira EP, Ferreira-Marçal PH (2017) Antibiofilm activity of cashew juice pulp against Staphylococcus aureus, high performance liquid chromatography/diode array detection and gas chromatography-mass spectrometry analyses, and interference on antimicrobial drugs. J Food Drug Anal. 25:589-596

24. Dias-Souza MV, Andrade S, Aguiar AP, Monteiro AS (2013) Evaluation of antimicrobial and anti-biofilm activities of Anacardium occidentale stem bark extract. J Nat Prod. 26:198e205

25. Dias-Souza MV, Caldoncelli JL, Monteiro AS (2013) Annacardium occidentale stem bark extract can decrease the efficacy of antimicrobial drugs. J Med Biol Sci 12:161e5

26. Hafidh RR, Abdulamir AS, Vern LS, Abu-Bakar F, Abas F, Jahanshiri F, Sekawi Z (2011) Inhibition of growth of highly resistant bacterial and fungal pathogens by a natural product. The Open Microbiol J. 5:96-106

27. Gonçalves FA, Andrade MN, Bezerra JNS, Macrae A, Sousa OVFF, Antonio A, Regine HSF (2008) Antibacterial activity of Guava, Psidium guajava Linnaeus, leaf extracts on diarrhea-causing enteric bacteria isolated from Seabob shrimp, Xiphopenaeus kroyeri (Heller). Rev Inst Med Trop. 50:11-15

28. Metwally AM, Omar AA, Harraz FM, El Sohafy SM (2010) Phytochemical investigation and antimicrobial activity of Psidium guajava L. leaves. Pharmacogn Mag. 6:212-218

29. Mahfuzul MDH, Bari ML, Inatsu Y, Juneja VK, Kawamoto S (2007) Antibacterial activity of guava (Psidium guajava L.) and Neem (Azadirachta indica A. Juss.) extracts against foodborne pathogens and spoilage bacteria. Foodborne Pathog Dis. 4:481-488

30. Biswas B, Rogers K, McLaughlin F, Daniels D, Yadav A (2013) Antimicrobial activities of leaf extracts of guava (Psidium guajava L.) on two gramnegative and gram-positive bacteria. Int. J Microbiol. $2013: 746165$

31. Rizwana H, Otibi FA, Al-malki N (2019) Chemical composition, FTIR studies and antibacterial activity of Passiflora edulis f. edulis (Fruit). J Pure Appl Microbiol 13:2489-2498
32. Penesyan A, Nagy SS, Kjelleberg S, Gillings MR, Paulsen IT (2019) Rapid microevolution of biofilm cells in response to antibiotics. NPJ biofilms and microbiomes 5:34 https://doi.org/10.1038/s41522-019-0108-3

33. Gupta K, Hazarika SN, Saikia D, Namsa ND, Mandal M (2014) One step green synthesis and anti-microbial and anti-biofilm properties of Psidium guajava L. leaf extract-mediated silver nanoparticles. Materials Letters 125:67-70

34. Tahara S, Miura Y, Mizutani J (1979) Antimicrobial I-5Alk(en)ylthiomethylhydantoin-( \pm -S-S-oxides: mode of action. Agric Biol Chem 43:919-924

35. Kovanda L, Zhang W, Wei X, Luo J, Wu X, Atwill ER, Vaessen S, Li X, Liu Y (2019) In vitro antimicrobial activities of organic acids and their derivatives on several species of gram-negative and gram-positive bacteria. Molecules 24:3770

36. Marçal PHF, Dias-Souza MV, Villela EG, Luz LM, Pereira MK, Vale CHB, Rabelo FLA (2014) Qualidade Físico-Química, Microbiológica e Microscópica de Polpas de Frutas Congeladas Comercializadas no Município de Governador Valadares, MG. Nova: Revista Científica 2:1-10

\section{Publisher's Note}

Springer Nature remains neutral with regard to jurisdictional claims in published maps and institutional affiliations.

\section{Submit your manuscript to a SpringerOpen ${ }^{\circ}$ journal and benefit from:}

- Convenient online submission

- Rigorous peer review

- Open access: articles freely available online

- High visibility within the field

- Retaining the copyright to your article

Submit your next manuscript at $\boldsymbol{\nabla}$ springeropen.com 